\title{
Microorganisms effects on radionuclides migration
}

\author{
Y. Andres, A. Abdelouas ${ }^{1}$ and B. Grambow ${ }^{1}$ \\ Ecole des Mines de Nantes, GEPEA, 4 rue A. Kastler, BP. 20722, \\ 44307 Nantes cedex 03, France \\ 1 SUBATECH, UMR 6457, Université de Nantes, École des Mines, IN2P3/CNRS, \\ 4 rue A. Kastler, BP. 20722, 44307 Nantes cedex 03, France
}

\begin{abstract}
In riatural systems, speciation and migration of heavy metals and radionuclides depend on many factors such as $\mathrm{pH}, \mathrm{Eh}$ and the presence of microorganisms. Microorganisms (bacteria, yeast, fungi) may have a direct action on the fate of metal ions through biosorption, bioaccumulation or resistance/detoxification processes. Microorganisms may influence the environment by producing mineral acids, chelating agents such as siderophore, or by-products from the metabolism (organic acids ...). In this paper, we report on microbial interaction processes including bioaccumulation, the indirect metal use for microbial life, the interaction with chelating agents, the resistance/detoxification mechanisms and some indirect influences of microorganisms on the speciation of metals. Also, we present some results of biosorption experiments with caesium, technetium, uranium, nickel and gadolinium using a variety of microbial strains. Saturation curves and Scatchard model were established for all biosorbants used in this work. For instance, the biosorption capacity for $\mathrm{Gd}^{3 *}$ ranged from $350 \mu \mathrm{mol} . \mathrm{g}^{-1}$ for $B$. subtilis to $5.1 \mu \mathrm{mol} . \mathrm{g}^{-1}$ for $S$. cerevisiae. We found that biosorption could be influenced by the growth stage and by the composition of the growth medium of microbial cells. Finally, we will present some results of uranium reduction by subsurface sulfate-reducing bacteria. The reduced uranium precipitated as uraninite.
\end{abstract}

\section{INTRODUCTION}

In natural surface and groundwater systems, the speciation and the migration of heavy metals and radionuclides depend on many factors such as the $\mathrm{pH}$, the Eh and the microbiological activity.

Microorganisms (bacteria, yeast, fungi) may have a direct action on metal mobility through biosorption, bioaccumulation or resistance/detoxification processes [1]. In addition, they may influence the environment by producing mineral acids, chelating agents such as siderophore, or by-products from the metabolism (organic acids ...). In this paper, we present, some examples of the microbial interaction processes including biosorption, the interaction with chelating agents, the indirect metal use for microbial life, bioaccumulation and the resistance/detoxification mechanisms and some indirect influences of microorganisms on the speciation of metals and / or radionuclides.

Biosorption is a physico-chemical mechanism including sorption, surface complexation, ion exchange and entrapment which are relevant for living and dead biomass as well as derived products. The solubilisation of metal oxides could occur by an interaction with chelators like siderophores [2] or with organic compounds such as acetate, gluconate and citrate [3]. Modification of the chemistry and redox conditions of environment could be caused by sulfide-oxidizing or sulfate-reducing bacteria. In fact, oxidation of sulfides such as pyrite $\left(\mathrm{FeS}_{2}\right)$ by Thiobacillus sp. under aerobic conditions leads to acidification of medium via sulfuric acid production, while sulfide produced by sulfate-reducing bacteria such as Desulfovibrio species can react with metallic ions ( $\mathrm{Fe}, \mathrm{Zn}, \mathrm{Ni}, \mathrm{Cd}, \mathrm{Pb} \ldots$ ) to produce sparingly soluble minerals [4]. Bioaccumulation which needs the microbial viability, corresponds to a passive or active uptake of ions by ionic channels or by specific carriers located in the cellular layers.

\section{DISCUTION}

\subsection{Biosorption}

Biosorption can be considered as the first step in the microorganism-metal interaction. It encompasses the uptake of metals by the whole biomass (living or dead) through physico-chemical mechanisms such as sorption, surface complexation, ion exchange or surface precipitation. These mechanisms take place on the cell wall [5] which is a rigid layer around the cell and they have fast kinetics. 


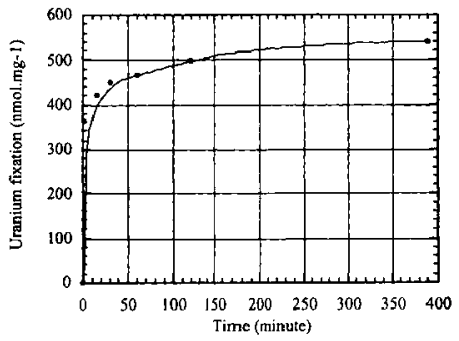

Figure 1: Kinetics of adsorption of uranium at $\mathrm{pH} 7$ by Thiobacillus intermedius (experimental conditions: $1 \%$ biomass and initial uranium concentration of $\left.68 \mathrm{mmol} . \mathrm{L}^{-1}\right)$. The major uranium species in solution are $\left(\mathrm{UO}_{2}\right)_{3}(\mathrm{OH})_{5}{ }_{5}^{+}$and $\left(\mathrm{UO}_{2}\right)_{4}(\mathrm{OH})_{4}$.

Figure 1 shows that the equilibrium state is obtained within a few minutes, for the adsorption of uranium by Thiobacillus intermedius at $\mathrm{pH} 7$. One dominant factor affecting the capacity of the microbial cell wall to "trap" the metal ion is the composition of this outer layer. The cell wall structure of microorganisms shows the presence of some free moieties, like amine, carboxylic, phosphates functions, which could be involved in the biosorption mechanisms of metallic ions [6].

\subsubsection{Cell wall characteristics}

Potentiometric titrations have shown that the metal ions fixation takes place on acidic moieties. This method can be used to measure the global pKa. For Pseudomonas aeruginosa, the pKa values are 2.8 and 6.1 , and allow us to conclude that the cell wall layers present two kinds of acidic function. Fein $e t$ al. [7] have characterized the acid/base properties of the cell wall of Bacillus subtilis and have shown three distinct types of surface organic acid functional groups with $\mathrm{pKa}$ of $4.82,6.9$ and 9.4 . These various values are generally attributed to carboxyl, phosphate and hydroxyl moieties. For Gram negative bacteria, the functional groups are, for example, present in the lipopolysaccharide of the outer layer and in the peptidoglycan and for Gram positive bacteria in the techoic acid. Mullen et al [8] have indicated, after electronic microscopy studies, that lanthanum was accumulated at the surface of $P$. aeruginosa inducing crystalline precipitation.

Time resolved laser spectrofluorimetry observations of europium ions have shown two main peaks around 592 and $615 \mathrm{~nm}$ which correspond respectively to the transition from ${ }^{5} \mathbf{D}_{0}$ toward ${ }^{7} \mathbf{F}_{1}$ and ${ }^{7} \mathbf{F}_{2}$ multiplet. The europium bound onto bacterial cells, presents two different lifetimes of 254 and $677 \mu s$ indicating two distinct environments for this fixed cation. The comparison of lifetimes of standard compounds (Eu-oxalate, $239 \mu \mathrm{s}, \mathrm{Eu}\left(\mathrm{PO}_{4}\right), 745 \mu \mathrm{s}$ ) suggests that this cation interacts with carboxylic or phosphate functions in the cell wall of Pseudomonas aeruginosa [9].

\subsubsection{Biosorption capacities}

Differences in the structures of cell walls lead to variations in the sorption capacity illustrated in table 1. For example, the biosorption capacity for $\mathrm{Gd}^{3+}$ ranged from $350 \mu \mathrm{mol} \cdot \mathrm{g}^{-1}$ for Bacillus subtilis to 5.1 $\mu \mathrm{mol} . \mathrm{g}^{-1}$ for Saccharomyces cerevisiae and the fixation of uranyl ions from $756 \mu \mathrm{mol} . \mathrm{g}^{-1}$ for Rhizopus arrhizus to $170 \mu \mathrm{mol} g$ for Mycobacterium smegmatis. More over, the medium used for the microbial growth before the cells were harvested, washed, and added to the metallic ions, could affect the biosorption capacities (for example see the case of Ralstonia metallidurans in table 1). In addition, the physiological state in wich the cells are harvested influence the fixation of gadolinium by Mycobacterium smegmatis (table 1).

No microbial uptake could be observed by Pseudomonas aeruginosa with caesium and technetium (VI), at $\mathrm{pH} \mathrm{7,} \mathrm{[10].} \mathrm{For} \mathrm{this} \mathrm{latter} \mathrm{element} \mathrm{the} \mathrm{main} \mathrm{species} \mathrm{in} \mathrm{solution} \mathrm{is} \mathrm{TcO}_{4}{ }^{-}$and the global charge of the cell wall layer at $\mathrm{pH} 7$ is negative, which suggests a repulsive mechanism between $\mathrm{Tc}$ and the biomass. Caesium is known to be an element which presents a poor sorption capacity [11]. We conclude that biosorption depends on cation chemistry and on composition, structure and nature of the bacterial layers. 
Tableau 1 : Biosorption capacities for various metallic ions by different microbial biomass.

(a) Cells harvested in the early stationary phase (b) Cells starved 15 days in stationary phase; (c) Ralstonia melallidurans CH34 (Alcaligenes eutrophus CH34) grown in 869 medium (rich) and (d) in 284 medium (synthetic)

\begin{tabular}{|c|c|c|c|}
\hline & Element & $\begin{array}{c}\text { Biosorption } \\
\text { umol.g } \\
\text { (dry weight) }\end{array}$ & References \\
\hline Mycobaclerium smegmatis (CIP 73.26) & $\begin{array}{l}\mathrm{La}^{3+} \\
\mathrm{Eu} 3+ \\
\mathrm{Yb}^{3+} \\
\mathrm{Gd}^{3+} \\
\mathrm{Gd}^{3+} \\
\mathrm{UO}_{2}{ }^{2+} \\
\mathrm{Th}^{4+}\end{array}$ & $\begin{array}{c}57 \\
101 \\
103 \\
110(a) \\
190(b) \\
170 \\
187\end{array}$ & $\begin{array}{l}{[12]} \\
{[13]} \\
{[14]} \\
{[13]}\end{array}$ \\
\hline Pseudomanas aeruginosa PU $2 \mathrm{I}$ & $\begin{array}{c}\mathrm{Hg}^{2+} \\
\mathrm{Pb}^{2+} \\
\mathrm{Cd}^{2+}\end{array}$ & $\begin{array}{l}969 \\
531 \\
362 \\
\end{array}$ & $\begin{array}{l}{[15]} \\
{[16]}\end{array}$ \\
\hline Pseudomonas aeruginosa & $\mathrm{UO}_{2}^{2+}$ & 630 & {$[17]$} \\
\hline Pseudomonas aeruginosa (CIP A 22) & $\begin{array}{l}\mathrm{La} 3+ \\
\mathrm{Eu}^{3+} \\
\mathrm{Yb}^{3+} \\
\text { Gd } 3+\end{array}$ & $\begin{array}{l}397 \\
290 \\
326 \\
322 \\
\end{array}$ & {$[18]$} \\
\hline Saccharomyces cerevisice & $\begin{array}{c}\mathrm{Zn}^{2+} \\
\mathrm{Cd}^{2+} \\
\mathrm{UO}_{2}^{2+} \\
\mathrm{Th}^{2+} \\
\mathrm{Gd}^{3+}\end{array}$ & $\begin{array}{c}260 \\
632 \\
630 \\
500 \\
5\end{array}$ & $\begin{array}{l}{[19]} \\
{[20]} \\
{[17]} \\
{[21]} \\
{[14]}\end{array}$ \\
\hline Ralstonia metallidurans $\mathrm{CH} 34$ & $\begin{array}{l}\text { Gd } \\
\text { Gd } \\
\end{array}$ & $\begin{array}{l}147(\mathrm{c}) \\
40 \text { (d) }\end{array}$ & [14] \\
\hline Bacillus subtilis & $\mathrm{Gd}^{3+}$ & 350 & {$[14]$} \\
\hline Penicillium chrysogenum & $\begin{array}{c}\mathrm{Pb}^{2+} \\
\mathrm{UO}_{2}{ }^{2+}\end{array}$ & $\begin{array}{l}559 \\
336 \\
\end{array}$ & $\begin{array}{l}{[22]} \\
{[23]}\end{array}$ \\
\hline Rhizopus nigricans & $\mathrm{Zn}^{2+}$ & 220 & {$[19]$} \\
\hline Rhizopus arthizus & $\begin{array}{c}\mathrm{Cu}^{2+} \\
\mathrm{Cd}^{2+} \\
\mathrm{Hg}^{2+} \\
\mathrm{Pb}^{2+} \\
\mathrm{UO}_{2}^{2+} \\
\mathrm{Th}^{2+}\end{array}$ & $\begin{array}{l}252 \\
267 \\
289 \\
502 \\
756 \\
733 \\
\end{array}$ & $\begin{array}{l}{[24]} \\
{[25]}\end{array}$ \\
\hline Aspergillus niger & $\begin{array}{l}\mathrm{Zn}^{2+} \\
\mathrm{Au}^{+}\end{array}$ & $\begin{array}{l}210 \\
862 \\
\end{array}$ & $\begin{array}{l}{[19]} \\
{[22]}\end{array}$ \\
\hline Zoogloed ramigera & $\begin{array}{l}\mathrm{Pb}^{2+} \\
\mathrm{Cu}^{2+} \\
\mathrm{Ni}^{2+}\end{array}$ & $\begin{array}{l}392 \\
536 \\
791 \\
\end{array}$ & [26] \\
\hline Sterile Activated sludge & $\begin{array}{l}\mathrm{Cd}^{2+} \\
\mathrm{Zn}^{2+} \\
\mathrm{Ni}^{2+}\end{array}$ & $\begin{array}{l}325 \\
392 \\
369\end{array}$ & [27] \\
\hline
\end{tabular}

\subsubsection{Effects of competing ions}

Multi-elemental studies show that in the case of lanthanum, europium and ytterbium the fixation takes place at the same cell wall site [18]. This work has pointed out a preferential adsorption for europium ions by a Pseudomonas aeruginosa biomass. The influence of the presence of cations $\left(\mathrm{Al}^{3+}, \mathrm{Ca}^{2+}, \mathrm{Na}^{2}, \mathrm{~K}^{+}\right.$) and anions $\left(\mathrm{NO}_{3}^{-}, \mathrm{SO}_{4}^{2-}, \mathrm{Cl}^{-}\right)$on biosorption performances has also been studied. Aluminum seems to be the more competitive ion for the fixation of europium, lanthanum and ytterbium by $P$. aeruginosa. The presence of glutamate, sulphate, phosphate, carbonate, chloride and ethylenediaminetetraacetate (EDTA) in solution with metal / complexant ratios up to 15, affects the biosorption of lanthanum by a Rhizopus arrhizus biomass [28]. Furthermore, the biosorption of lanthanum by Mycobacterium smegmatis is greatly decreased by the presence in solution of thorium or uranyl ions at $\mathrm{pH} 1.0$ [13]. Karavaiko et al. [29] have obtained results of the decrease (values from 56 to $94 \%$ ) of scandium biosorption by various microorganisms in the presence of aluminum, iron and titanium. Tsezos $e l a l$. [30] bave studied the effect of competing ions on the biosorption of metals in relation to their Pearson classification (soft, hard and borderline species). In the case of the "hard-hard" pair represented by uranium and yttrium, the biosorption of the latter is strongly depressed. More generally, a significant ionic competition effect is observed for metals belonging to the same class. 


\subsection{Complexing substances}

Bacteria and fungi can produce many complexing or chelating substances. The mobilization capacities of a bacterial and fungal iron chelating agent, for plutonium and uranium, have been studied by Brainard $e t$ al. [31]. They used two siderophores: the first produced by Escherichia coli (enterochelin) with catechol functions, and the second, by Streptomyces pilosus (desferrioxamin B), with hydroxamate groups. They showed that plutonium and uranium oxides could be solubilised by these molecules. A review has been published by Fogarty and Tobin [32] about the complexation between fungal melanins and metal ions $(\mathrm{Ni}, \mathrm{Cu}, \mathrm{Zn}, \mathrm{Cd}, \mathrm{Pb}$ etc...). These compounds are dark brown or black pigments located in the cell walls. Fungi are also able to produce small organic acids (gluconic, oxalic etc....) which can react with metallic oxides and lead to their solubilizations.

\subsection{Indirect influences}

Figure 2 and 3 shown the two main indirect mechanisms of interaction which are related to the change in $\mathrm{pH}$ or redox conditions of the medium.
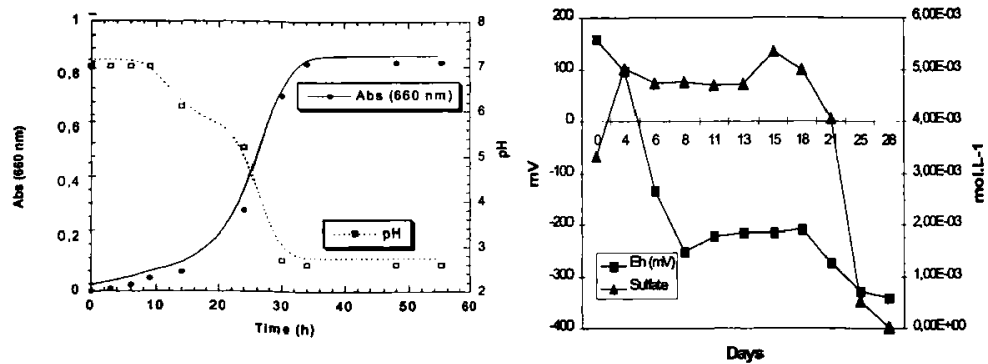

Figure 2: Medium acidification by Thiobacillus intermedius in relation with growth.

Figure 3: Sulfate consumption by subsurface sulfate reducing bacteria.

In the presence of air, sulfur oxidizing bacteria (SOB) such as Thiobacillus use sulfide minerals (FeS2, $\mathrm{Cu}_{2} \mathrm{~S}, \mathrm{PbS}$....) for their growth. These reactions can produce mineral acids which modify the $\mathrm{pH}$ of the medium. The direct microbial oxidation of iron pyrite is summarized by the following reaction:

$$
\mathrm{FeS}_{2}+3.5 \mathrm{O}_{2}+\mathrm{H}_{2} \mathrm{O} \stackrel{\text { Bacteria }}{\longrightarrow} \mathrm{Fe}^{2+}+2 \mathrm{SO}_{4}^{2-}+2 \mathrm{H}^{+}
$$

Under reducing conditions sulfate-reducing bacteria (SRB) such as Desulfovibrio species are capable of reduction of sulfate into sulfide, which reacts with metal ions to precipitate highly insoluble sulfides [3] : NiS, $3 \times 10^{-21}$; Cu2S, $2.5 \times 10^{-50}$; CoS, $7 \times 10^{-23}$; PbS, $1 \times 10^{-29} ; \mathrm{HgS}, 3 \times 10^{-53}$ ). Also, dissolved sulfide ions can directly reduce metals including $\mathrm{U}(\mathrm{VI}), \mathrm{Cr}$ (VI) and $\mathrm{Tc}$ (VII). Reduction of sulfate requires organic carbon like natural organic matter or more simple compounds such as lactate, ethanol and acetate or $\mathrm{H}_{2}$ as electron donnor:

$$
\mathrm{SO}_{4}^{2-}+\text { organic matter } \stackrel{\mathrm{SRB}}{\longrightarrow} \mathrm{HS}^{-}+\mathrm{H}_{2} \mathrm{O}+\mathrm{HCO}_{3}^{-}
$$




\subsection{Indirect metal use for microbial life}

Some microorganisms are able to grow under anaerobic conditions by coupling the oxidation of simple organic substances with the reduction of metallic compounds. For example, the simplified equation of the reduction of uranyl ions (U VI) by Shewanella putrefaciens [34] in presence of hydrogen can be written as:

$$
\mathrm{H}_{2}+\underset{\text { Soluble }}{\mathrm{U}(\mathrm{VI})} \longrightarrow 2 \mathrm{H}^{+}+\underset{\text { Insoluble }}{\mathrm{U}(\mathrm{IV})}
$$

Uranium can be reduced by a variety of metal- and sulfate-reducing bacteria [35-37]. Pure or mixed cultures of these bacteria can couple the oxidation of organic compounds (lactate, formate, ethanol) or $\mathbf{H}_{2}$ to the reduction of $\mathrm{U}(\mathrm{VI})$. The reduced $\mathrm{U}$ precipitates as the highly insoluble mineral uraninite $\left(\mathrm{UO}_{2}\right)$. Abdelous et al. [37] showed that subsurface sulfate-reducing bacteria from a mill tailings site are capable of reducing $U(V I)$, which precipitates at the periphery of the cell (Figures 4 and 5). Enzymatic reduction of $U$ was shown by Lovley et al. [38]. The authors showed that the cytochrome $c_{3}$ enzyme, which is located in the soluble fraction of the periplasmic region of Desulfovibrio vulgaris, reduced $\mathrm{U}(\mathrm{VI})$ in the presence of excess of hydrogenase and $\mathrm{H}_{2}$. In natural reducing environments metaland sulfate-reducing bacteria are expected to play a significant role in uranium immobilization.

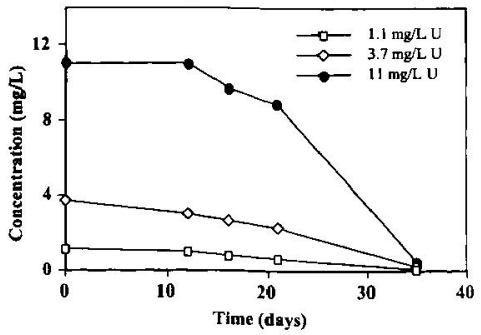

Figure 4: Reduction of U(VI) by subsurface sulfate-reducing bacteria in groundwater from a mill tailing site amended with ethanol and phosphate.

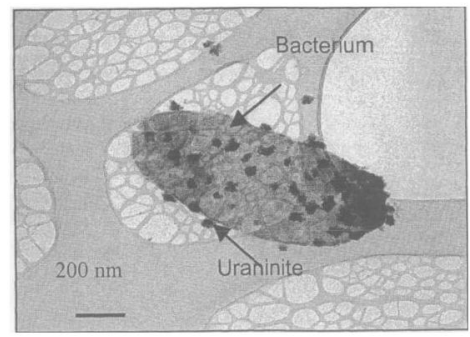

Figure 5: Lraninite particles un the surtace of a sulfitereducing bacterium in groundwater from a mill tailing site amended with ethanol and phosphate.

\subsection{Bioaccumulation}

Bioaccumulation is one kind of the possible interactions between microorganisms and metal ions in relation with metabolic pathways; it needs living cells. Metal ions are involved in all aspects of the microbial growth. Many metals are essential, whereas others have no known essential biological function. Accumulation of radionuclides through the pathways of their stable isotopes or of chemically homologous elements can be considered as bioaccumulation. It is well known that caesium ion can be accumulated by the channel of potassium [11].

\subsection{Resistance and detoxification mechanisms}

In a polluted environment, microorganisms are able to develop a great diversity of resistance and detoxification mechanisms. The most important is the transformation of toxic species into inactive forms, by reduction, methylation or precipitation. For example, the predominant redox states of selenium in natural environment are $\mathrm{Se}(\mathrm{VI})\left(\mathrm{SeO}_{4}{ }^{2}\right)$ and $\mathrm{Se}(\mathrm{IV})\left(\mathrm{SeO}_{3}{ }^{2-}\right)$, which can be reduced into elemental selenium $\mathrm{Se}(0)$ by telluric (Clostridium, Citobacter, Flavobacterium, Pseudomonas...) or by bacteria in anoxic aquatic sediments bacteria [39]. The oxianion species can potentially serve as electron acceptors for the microbial metabolism. Another way of transformation is the biomethylation of inorganic selenium 
compounds in dimethylselenide $\left[\left(\mathrm{CH}_{3}\right)_{2} \mathrm{Se}\right]$. The methylated species are generally volatile in environmental conditions [40] and may have a great influence on migration of these heavy metals.

\section{CONCLUSION}

Microorganisms can be considered as potential vectors for radionuclides and metals migration and retention through bioaccumulation and associated mechanisms, and through biosorption. It has been shown that their fixation capacities are more or less important, depending on the structure of the cell wall, the medium conditions and the speciation of the metal ions. Metal ions can either be extracted from a solid matrix and then dispersed in the environment by microbial actions or mobile metal ions can be immobilized by the action of microorganisms.

This presentation is not an exhaustive explanation of microorganism-metal interactions, but we have presented the phenomena which could have an implication in migration/retention of radionuclides.

\section{Acknowledgments}

The authors are grateful to ANDRA for supporting some part of the present works.

\section{References}

[1] Gadd G.M. and White C., TIBTECH 11 (1993) 353-59.

[2] Hernlem B.J., Vane L.M., Sayles G.D., Wat. Res. 33 (1999) 951-960.

[3] Krebs W., Brombacher C., Bosshard, P., Bachofen R. Brandl H., FEMS Microbiology Reviews 20 (1997) 605-617.

[4] Ehrlich H.L., Geomicrobiology of sulfur. In: Geomicrobiology 3nd ed., Marcel Dekker, Inc. New York, (1996) pp. 508-559.

[5] Shumate II and G.W. Strandberg: Comprhensive biotechnology, Pergamon Press, New York, 4 (1985)

[6] Remacle J. Biosorption of heavy metals, CRC PRESS, Boca Raton, (1990) pp 83

[7] Fein J. B., Daughney C. J., Yee N. and Davis T., Geochim. Cosmoschim. Acta 61 (1997) 3319-3328.

[8] Mullen M. D., Wolf D. C., Ferris F. G., Beveridge T. J., Flemming C. A. and Bailley G. W, Appl. Environ. Microbiol. 55 (1986) 3143-3149.

[9] Texier A. C., Andrè Y., Illemassene M. and Le Cloirec P., Environ. Sci. Technol. 34 (2000)610-615.

[10] Andrès Y., Redercher S., Gerente C. and Thouand G., J. Radioanal. Nucl. Chem. 247 (2001) 89-93.

[11] Avery S.V., J. Chem. Tech. Biotechnol. 62 (1995) 3-16.

[12] Texier A. C., Andrès Y. and Le Cloirec P., Environ. Technol 18 (1997) 835-841.

[13] Andrès Y., MacCordick H.J. and Hubert J.C., App. Microbiol. Biotechnol. 39 (1993) 413-417.

[14] Andrès Y., Thouand G., Boualam M and Mergeay M., App. Microbiol. Biotechnol. 54 (2000) 262

[15] Chang J.S. and Hong J., Biotechnol. Bioeng. 44 (1994) 999.1006

[I6] Chang J.S., Law R. and Chang C.C., Wat. Res. 31 (1997) 1651-1658.

[17] Strandberg G.W., Shumate I S.E., Parrot J.R, Appl. Environ. Microbiol. 41 (1981) 237-245

[18] Texier A. C., Andrès Y, and Le Cloirec P., Sci. Technol., 33 (1999) 489-495.

[19] Volesky B., FEMS Microbiol. Rev. 14 (1994) 291-302.

[20] Volesky B., May H. and Holan Z.R., Biotechnol. Bioeng. 41 (1993) 826-829.

[21] Gadd G.M., Experientia 46 (1990) 834-840.

[22] Kapoor A. and Viraraghavan T., Biores. Technol. 53 (1995) 195-206.

[23] Jilek R., Prochazka H., Stamberg K. Katzer J. and Nemec P., Rudy 23 (1975) 282-286.

[24] Tsezos M. and Volesky B., Biotechnol Bioeng. 24 (1982) 385-401.

[25] Tsezos M. and Volesky B., Biotechnol. Bioeng. 24 (1982) 955-969.

[26] Sag Y. and Kutsal T., Biochem. Eng. J. 60 (1995) 181-188.

[27] Solaris P., Zouboulis A.I., Matis K.A. and G.A. Stalidis. Separation Sci. Technol. 31 (1996) 1075 -

[28] Tobin J.M., Cooper D.G. and Neufeld R.J., Biotechnol. Bioeng 30 (1987) 882-886.

[29] Karavaiko G.I., Kareva A.S., Avakian Z.A., Zakharova V.I. and Korenevsky A.A., Biotechnol. Letters 18 (1996)1291-1296.

[30] Tsezos M., Remoudaki E. and Angelatou V., Int. Biodeter. \& Biodeg. (1996) 19-29.

[31] Brainard J.R., Strietelmeier B.A, Smith P.H., Langston-Unkefer P.J., Barr M.E. and Ryan R.R. Radiochimica acto 58/59 (1992) 357.

[32] Fogarty R.V. and Tobin J.M.,., Enz. Microbial Technol. 19 (1996) 311

[33] Andrès Y., MacCordick H. J. and Hubert J. C., Biol. Metals 4 (1991) 207-210.

[34] Lovley D.R., J. Ind. Microbiol. 14 (1995) 85-93

[35] Lovley DR, Phillips EJP, Gorby YA, Landa ER., Nature 350 (1991) 413-416. 
[36] Abdelouas A, Lutze W, Nuttall HE. In: Uranium: Mineralogy, Geochemistry and the Environment. Reviews in Mineralogy, Vol. 38 (P. C. Burns and R. Finch, eds.), (1999) pp 433-473.

[37] Abdelouas A., Lutze W., Gong W., Nuttall H.E., Strietelmeier B.A. Travis B.J., The Sci. Total Environ. 250 (2000) 21-35.

[38] Lovley, D. R., Widman, P. K., Woodward, J. C., Phillips, E. J. P., Appl. Anviron. Microbiol. 59 (1993) 3572.

[39] D.R. Loveley: Annu. Rev. Microbiol. 47 (1993) 263

[40] G.M. Gadd: FEMS Microbiol. Rew. 11 (1993) 297 